\title{
The Research on the Factors Analysis of Platform Economy City: A Case Study of Shanghai
}

\author{
Ying Chen ${ }^{1} \&$ Zhengyang Chen ${ }^{1}$ \\ ${ }^{1}$ SILC business school, Shanghai University, Shanghai, P. R. China \\ Correspondence: Ying Chen, SILC Business School, Shanghai University, Chengzhong road 20, Jiading district, \\ Shanghai, 201800, P. R. China. E-mail: dorothychen@staff.shu.edu.cn
}

Received: November 14, 2015

Accepted: November 27, 2015 Online Published: December 18, 2015

doi:10.5539/ijbm.v11n1p85

URL: http://dx.doi.org/10.5539/ijbm.v11n1p85

\begin{abstract}
The enterprises of platform economy became the driving force and the engine for the development of economy. The industry of platform economy would be the leading industry and accelerate the city development and transformation in the future. The platform economy cities were the cities which provided the real or virtual platform space for the enterprises or individuals dealing with the trading activities and collaborating with externalities of urban platforms. The development of Shanghai was becoming the highly influential city in the network of global cities.
\end{abstract}

Keywords: platform economy, platform economy city, global city

\section{Background: The Development of Platform Economy}

Throughout the history in the development of the enterprises of platform economy, it could be divided into the following stages. The first stage was the operations of platform economy in the traditional age. For example, the bank cards were a kind of convenient settlement services that provided for businesses and consumers by commercial banks. And the gaming operators offered the users with gaming entertainment platform service. People did not have clearly understanding on the platform mode. The second stage was the times of software development and internet application. For example, the software of operating system platforms marked by the appearance of Microsoft Windows charged for the software packages on which could use a series of software developed by the other companies, everyone should pay for the platform software on any computer and this model brought huge profits to Microsoft. TaoBao Corp. was one of the China's most popular C2C sites, offering a wide range of affordable products to consumers. 1688 domestic trade market Corp. was one of the leading platforms of small businesses e-commerce. PayPal Corp. was the most widely used third-party online payment platform in China. Shop No. 1 Corp. was a comprehensive online supermarket of the e-commerce platform. Ctrip Corp. mixed the consumer-oriented model of BMC, B2C, O2O based on tourism market, including hotels, flight and travel booking services。People realized that it could generate enormous profits from the operating mode of the platform economy. The third stage was the mobile internet era. It was named by the emergence of Apple Corp. Anyone could develop their own software used for mobile phone and upload to App store, where it offered the services of software platform for mobile phone and the users could choose to download and install. It was the channel and the heights of mobile phone industry. Taxi drivers used mobile application software, such as Didi taxi, Uber, and it facilitated hundreds of millions of persons every day. Chinese Prime Minister Li completed the first lending business in Qianhai Bank which was the first bank served for small micro-enterprise commercial on the internet in Shenzhen on January 4,2015, opening a new era of internet financial services for personal services of consuming loans. The traditional enterprises and industries were integrated and transformed by platform economy and generated much more revenues and profits.

From the development the platform economy enterprises, in the past few day people ignored the traditional media and intermediary services. The concept of platform economy was also gradually into sight until 2000 . The traditional trading market was that the supply parties and demands parties were in the same market and increased social welfare, and market itself did not get profits. Otherwise there were also the multiple supply parties and demands parties in the enterprises of platform economy, which provided the platforms services and earned revenues from that, such as bank cards, telecommunications operations services. With the development of information and communication technology (ICT) and the popularization of the internet, internet storm gradually 
evolved and mobile internet speeded the sharing and transferring information and created many intelligent tools. These innovations played a crucial role in promoting leap-forward development in the enterprises of platform economy and traditional industries were subject to different degrees of influence. The enterprises of platform economy continuously expanded the business to traditional industries. For example, the ecological chain of the medical and healthy management on the internet included the electronically pharmacies and drug inspection, gradually breaking the original interest of industry monopoly and the value chain, improving people's lives and increasing social welfare. Traditional industries and human societies were also disruptively changed by the enterprises of platform economy. It provided virtual spaces for the businesses and individuals, reducing transaction costs for all participants and improving efficiency of the platform, and the enterprises of platform economy would earn much more profits. Platform economy and its business model had grown continuously and became the power and engine of economic development. With the introduction of the concept on platform economy, we could boldly predict that the leading industry would be the platform economy and could contribute to the transition in urban development in the future.

\section{Literature Review}

Firstly the researchers used world city to discuss the referent problem. Then, Sassen (1991) emphasized the economy fields in the city and first gave the concept of global city. Globalization and World City (GaWC) Research in UK accomplished many research on world city including economy, populations and environments, etc. Zhou (2008) Taylor et al. $(2011,2013)$ explained the special phenomena in Chinese cities. Peter J. Taylor (2013) discussed the global cities had the different levels of strategicness in interlocking network. An increasing number of the researchers Rochet (2003) Roson (2005) paid attention to platform economy. Xu (2007) analyzed the mode and strategy of platform economy industry and enterprises in China. However, few people combined the research on platform economy and global city together. So in this paper we discussed the problem.

\section{The Connotation of the Platform Economy City}

The concept of platform economy was applied to the related theoretical research on city development and construction. The trend of global integration intensified the competition among the countries. The status of the country in the global economic network was much more depending on the development of the global city in the country. All the cities were connected together by internet; cloud computing and other science and technology, the development of transportation and the speed of information delivery. Logistics, information flows, capital flows and talents flows formed a global network and closely linked together between countries and cities. Every city in the global network played a certain role. The city in the node of global network could be regarded as a city of platform economy and the different types of platform economy cities were carrying a significantly different role. Platform economy cities provided the real or virtual space for the various activities and facilitated the business or individuals trading, including logistics transportation, financial settlement and the movement of personnel, etc. Platform economy cities included much more platform industries, such as telecommunications, financial services, retail and media advertising, etc.

Global city was a certain kind of city that could affect economy, culture, and politics in the world and it was a platform provided for businesses from all over the world, with the ability to support and accommodate the largest economy in the global economic network. In the network of global economy, there were the platforms of global cities with a variety of horizontal and vertical industrial chain, industrial cluster and agglomeration, which were promoted the flows of talents, capitals, commodities and innovative technologies in the domestic markets and the international markets and reduced the barriers in international trading.

There were the large differences between the platform economy city and the platform economy enterprises. The platform economy enterprises provided various services by the operating platforms to benefits the all aspects parties to obtain economic profits. The cities of platform economy did not simply obtain commercial interests, but provided the public commodities, quasi-public commodities and other convenient supporting services to the enterprises and individuals to increase social welfare and the efficiency of production in society, to achieve a win-win situation on the leading of governments. Through the overall operation of the platforms of the cities and the connections among the cities with different functions, all cities united the huge system to operation and fully reflected the positive characteristics of external features in the city platforms, which could reduce the costs in previously administrative management system and each administrative region fragmented, gradually improve the management efficiency and increased social welfare. Nevertheless, in the course of the development and operating of the platform economy cities, there would be negative external features. But these problems were more easily exposed in the information sharing of urban economic platform. Based on the entire network of platform economy cities, the problem of information asymmetry and converse option issues would be solved in 
the coordinated perspective of platform economy city, reduced the interests of other subjects and formulated relevant laws and regulations, for example, the problems of environmental pollution, the supply and demand of talents, the sharing of technology and innovation.

It was generally the development laws of the industrial structure in global cities. The first industry was agriculture with very low percentage of GDP in the cities, including modern production and services with high technology. The second industry was traditional industrial manufacturing industry gradually reduced. The third industry was manufacturing services industry, such as finance, advertising, consulting etc., and consumer services industry, such as education, tourism, business services, health care, cultural and creative industries etc. And these combined with intelligent technology to build up smart cities. The development of platform economy enterprises and platform economy industry could break the rules of inherent development and the Internet technology would be the driving force to break the separation of the traditional industries, accelerating the upgrading of industries.

\section{The Methods and Data}

Based on the information technology (mobile internet, cloud computing, big data, Internet of things and so on), platform economy could fully integrate the industries, while allowing the participants to benefit from the platform and improve the overall productivity in society. The platform economy was a kind of global cross-border economy which was beyond the traditional geographical boundaries. It was an efficient allocation of global resources and supply and demand patterns, with the effects of scale economy and economies of scope. On the Internet information, platform economy was a continuous economic model. The platform economy was the integrated industry chains and value chains, including service industry, traditional manufacturing industry, high-tech industry, and so on. The characteristics of platform economy were their concentration, radiation and openness closely related to the regional deepening cooperation between Shanghai and the other global cities. To explore the development platform economy and promote regional cooperation was of great significance to the economic development of Shanghai.

The meeting of APEC first held in Oct. 2001 and the World Expo in 2010 rapidly promoted the development of convention and exhibition industry and had a great effect on the economy of Shanghai. In Sep. 2013, the free trade zone was established in Shanghai. The large events not only promoted the exchange of Chinese and foreign cultures, but also attracted the foreign investment.

There were 4 factors affecting the economic construction of the platform and 4 hypotheses:

H1: The level of a city of platform economy had a significant correlation with the times of the city's large-scale event.

H2: The level of a city of platform economy had a significant correlation with the number of functional platforms in the city.

H3: The level of a city of platform economy had a significant correlation with the number of international standard industry association.

H4: The level of a city of platform economy had a significant correlation with the number of functional groups in the city.

We used Global Power City Index (GPCI) as Y, published by in Japan to explain the influence of global city in the world. The Institute of city strategy in Mori Memorial Foundation had a certain frontier research in these areas and the research of GPCI began from 2008, which was the first organization in the world. Global city index of Kearney (GCI) was also released in 2008 in New York. However, Mori Memorial Foundation had the original assumptions. They thought that the evaluation criteria to attract talent and the main force of the enterprise were the comprehensive power of the city with the unique research methods, which selected 40 cities with 6 dimensions of the 70 indicators of research methods from four kinds of global participants: operators, researchers, artists and tourists; and a local participant: residents.

The data $X_{1}$ of large event was selected the number of positive reports from top international newspapers, including The Financial Times, The Los Angeles Times, The Straits Times, the English version of People's Daily, The Guardian, The Times, The Daily Telegraph, The Wall Street Journal, The New York Times, USA Today, Lian he Zao bao, Business Times, Can Kao Xiao Xi, Yomiuri Shim bun, Asahi news, searching the title of major events or the occurrence of the event in the city. Finally we got the accurate value. The data $X_{2}, X_{3}, X_{4}$ of functional platform meant all the information of the trading center, the exchange center, industry association, functional organization and the headquarters of the Multi-National Corporation. We calculated the correlation analysis as Table 1. 
Table 1 . The results of correlation analysis

\begin{tabular}{|c|c|c|c|c|c|}
\hline City & $\begin{array}{l}\text { Global Power } \\
\text { City Index Y }\end{array}$ & $\begin{array}{l}\text { The frequency of } \\
\text { large events } X_{1}\end{array}$ & $\begin{array}{l}\text { The number of } \\
\text { functional platforms } X_{2}\end{array}$ & $\begin{array}{l}\text { The number of } \\
\text { industry } \\
\text { associations } \mathrm{X}_{3}\end{array}$ & $\begin{array}{l}\text { The number of } \\
\text { functional } \\
\text { organizations } \mathrm{X}_{4}\end{array}$ \\
\hline London & 1457.9 & 2535 & 637 & 166 & 34 \\
\hline New York & 1362.9 & 2158 & 594 & 36 & 30 \\
\hline Paris & 1291.8 & 2375 & 299 & 204 & 32 \\
\hline Singapore & 1113.3 & 1163 & 277 & 175 & 12 \\
\hline Seoul & 1104.4 & 1408 & 239 & 125 & 13 \\
\hline Hong Kong & 985.8 & 644 & 592 & 89 & 14 \\
\hline Peking & 965.0 & 1602 & 447 & 105 & 25 \\
\hline Shanghai & 975.2 & 951 & 556 & 72 & 13 \\
\hline Saint Paul & 689.9 & 982 & 352 & 70 & 8 \\
\hline Mumbai & 633.9 & 237 & 473 & 19 & 7 \\
\hline
\end{tabular}

The graph of functional platform data was the head of the warped tail and middle depression. Through the observation data, we found that the main reason of middle depression was the restriction of urban region space. For the certain kinds of the city, such as Seoul, Singapore, Paris, the country was much more developed, it did not need to build more functional platform. The main reason was the rapid rise of developing countries, such as the typical representative of Shanghai, Beijing, and Mumbai. This kind of city was in a rapid development, because the economic strength was not strong, so the number of functional platform had a blowout, but not to form an effective scale, it could be explained that the expansion was too fast but the control was not enough.

The number of industry association was the number of international trade associations. Paris was the first city, then Singapore. The data of New York was far behind and the main reason was that the international conference was more dispersed in USA, a considerable part of the meeting was held in Los Angeles, Washington, Chicago and other cities of the same bustling international metropolis. At the same time, the number of international conferences in Shanghai was higher than that of Hong Kong, which also showed that the capital of a country had a significant impact on the number of international conferences held in Beijing.

It was not big that the overall deviation of data of the functional organization. From the data, London, New York, Paris, three of the top international metropolis had a distinct advantage. The middle of cities were intensive, Sao Paulo and Mumbai were at the bottom. It was mentioned that the international functional organization in Beijing was much higher than the same level cities, close to the first group. From the names of these organizations, the reason would be in the deeply cultural heritage and the capacity of international cultural exchange in Beijing.

\section{The Results of the Empirical Analysis on the Factors of Platform Economy in Shanghai}

Table 2. The fitting results of the equation

\begin{tabular}{lllllllll}
\hline & R2 & Sig. & B(constant) & B(X2) & B(X3) & B(Avg.X1+X4) & B(Sum) & B(Avg.X1+X4) - \% \\
\hline Y & 0.814 & 0.013 & 1058.01 & 51.497 & 80.236 & 187.754 & 319.487 & 0.587673 \\
\hline
\end{tabular}

Table 2 was the fitting results of the equation. And the goodness of fit of the equation was higher than 0.01 , and it was acceptable that the value of $\mathrm{P}$ in the confidence interval. That the four variables had a greater impact on the city's influence. The frequency of large events and the number of functional organizations had a high degree of positive correlation with Global Power City Index. And it was the weak correlation between the number of functional platforms, the international standard industry associations and Global Power City Index. Otherwise, we only thought of these four factors to analysis the degree of platform economy cities and found it was a very interesting topic to further research with questionnaire survey.

\section{References}

Amen, M., Toly, N., McCarney, P. et al. (2011). Sighting or slighting cities in international relations.

Bouteligier, S. (2009). Global cities and global environmental NGOs: Emerging transnational urban networks? In M. Amen et al. (Eds.), Cities and Global Governance: A New Site for International Relations (pp. 151-176). Burlington VT: Ashgate.

Castells, M. (1996). The rise of the network society. Blackwell publishers. 
Coe, N. et al. (2010). Making connections: Global Production Networks and World City Networks. Global Networks, (1), 138-149.

Derudder, B., Taylor, P. J., Hoyler, M. et al. (2013). Measurement and interpretation of connectivity of Chinese cities in the world city network. Chinese Geographical Science, 23(3), 261-273. Htpp://dx.doi.org/10.1007/s11769-013-0604-y

Derudder, B., \& Witlox, F. (2010). World Cities and Global Commodity Chains: An introduction. Global Networks, 10(1), 1-11.

Friedman, J. (1986). The world city hypothesis. Development and Change, 17(1), 69-83.

Hall, P. G. (1966). The world cities. London: Weidenfeld and Nicolson.

Knox, P. L., \& Taylor, P. J. (1995). World cities in a world system. Cambridge University Press.

Kratke, S. (2011). How Manufacturing Industries Connect Cities across the World: Extending Research on Multiple Globalizations. Retrieved from http://www.lboro.ac.uk/gawc/rb/rb391.html

Lambregts, B. (2009). The Polycentric Metropolis Unpacked: Concepts, Trends and Policy in the Randstad Holland. Amsterdam institute for Metropolitan and International Development Studies.

Mei, L., Su, N., \& Xue, D. S. (2012). Research on temporal spatial process and dynamics of transnational institutions in Guangzhou. Human Geography, 1(23), 66-71.

Peter, J. T., Ben, D., James, F., Michael, H., \& Pengfei, N. (2013). Advanced Producer Service Firms as Strategic Networks, Global Cities as Strategic Places. Economic Geography, 90(3), 267-291.

Rao, G. P., \& Huang, Y. (2005). Mutuality of international organization and the globalization process, International Organizations in the Process of Globalization. Beijing: Peking University Press.

Rochet, J., \& Tirole, J. (2003). Platform competition in two-sided markets. Journal of European Economic Association, 1, 990-1029.

Roson, R. (2005). Two-sided markets: A tentative survey. Review of Network Economics, 4(2), 142-160.

Sassen, S. (1991). The global city: New York, London, Tokyo. Princeton University Press.

Sassen, S. (1995). On concentration and centrality in the global city. World Cities in a World System, 63, 71.

Taylor, P. J. (1997). Hierarchical tendencies amongst world cities: A global research proposal. Cities, 14(6), 323-332.

Taylor, P. J. (2005). New political geographies: Global civil society and global governance through world city networks. Political Geography, 24(6), 703-730. http://dx.doi.org/10.1016/j.polgeo.2005.01.009

Taylor, P. J., Derudder, B., Hoyler, M., \& Ni, P. (2013b). New regional geographies of the world as practised by leading advanced producer service firms in 2010. Transactions of the Institute of British Geographers, 38, 497-511.

Taylor, P. J., Derudder, B., Hoyler, M., Ni, P., \& Witlox, F. (2013a). City-dyad analyses of China's integration into the world city network. Urban Studies.

Taylor, P. J., Ni, P., Derudder, B. et al. (2011). Global Urban Analysis: A Survey of Cities in Globalization. London: Earthscan

Xu, J. (2007). Platform Economics. Shanghai Jiao Tong University Press.

Zhen, F., Wang, X., Yin, J. et al. (2013). An empirical study on Chinese city network pattern based on producer services. Chinese Geographical Science, 23(3), 274-285. http://dx.doi.org/10.1007/ s11769-013-0595-8

Zhou, Z. H. (2008). A study on Globalizing Cities: The Studies on Theory Frames and Chinese Model. Shanghai: Shanghai People Press.

\section{Copyrights}

Copyright for this article is retained by the author(s), with first publication rights granted to the journal.

This is an open-access article distributed under the terms and conditions of the Creative Commons Attribution license (http://creativecommons.org/licenses/by/3.0/). 